\title{
Isolation and Identification of Saccharomyces cerevisiae var boulardii and its Uses as a Probiotic (in vitro)
}

\author{
*Zainab M. AL Zubaidy \\ Department of Food Technology \\ College of Agriculture \\ University of Salahaddin
}

*Email: Zalzubaidii@yahoo.com

(Received 13/3/2013 ; Accepted 10 / 6/2013)

\begin{abstract}
The study included isolation and identification of Saccharomyces cerevisiae var. boulardii from fresh and dried fruits such as (fig, grape, apricot, lychees, mangosteen) which were available in local markets in Erbil city. Fifty isolates of the yeast were obtained depending on morphological, physiological and biochemical tests. The antibacterial activity of the isolated yeasts against pathogenic bacteria Salmonella enteric sub spp.enterica (Typhimurium) in vitro was determined by Well's Diffusion method. Most of the isolated yeasts showed antibacterial activity against tested bacterium, the highest diameter of inhibition zone was $(16 \mathrm{~mm})$ for isolates (S.b32). The ability to tolerate different concentrations of bile salt and gastric acids were also studied. Ten strains of the isolated yeast had the highest inhibitory activity and were used to study physiological properties (bile salt concentration and gastric acidity) which were (S.b6, S.c1, S.b2, S.c36, S.b13, S.b28, S.b32, S.b22, S.b48, and S.b5). The result showed that the isolate (S.b32) was more resistant than other strains when exposed to bile salt and gastric acids.
\end{abstract}

Keywords: Saccharomyces cerevisiae, probiotic.

\section{Saccharomyces cerevisiae var. boulardii}

\section{أحياءاً علاجية في المختبر (in vitro)}

\section{الملغص}

تصنمت الدرلسة عزل وتشخيص خميرة من الفولكه الطازجة والمجففة مل (العنب والتن والمشهش والمانغوستين واللايتشي) المتوفرة في الأسواق المحلية في مدينة اربيل. ومت الحصول على 50 عزلة من خميرة Saccharomyces cerevisiae var. boulardii

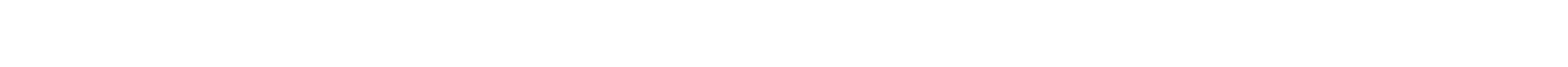
ب. Salmonella enteric sub spp. enterica (Typhimurium) (Well Diffusion) 
كلت (16 كملم) ضد S.Typhimurium للعزلة (S.b32). عثرة عزلات أظلهرت أعلى فعالية تشبطية لستعملت

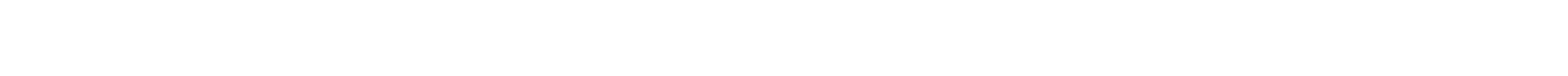

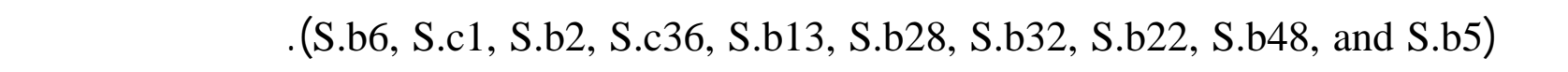
الصفلت الفسلجية لعزلات الخمائر لوطظ ان العزلة(S.b32)كلت لكثر مقاومة من العزلات الأخرى لتركيز مختلفة من أملاح الصفراء والحولمض المعوية.

الكاملت الدالة: Saccharomyces cerevisiae, probiotic.

\section{INTRODUCTION}

Sacch. cerevisiae var boulardii possesses many properties that make it a potential probiotic survives transit through the GI tract, it's temperature optimum is $37^{\circ} \mathrm{C}$, both in vitro and in vivo, it inhibits the growth of a number of microbial pathogens. However, Sacch. cerevisiae var boulardii belongs to the group of simple eukaryotic cells and, it thus differs from bacterial probiotics that are prokaryotes. Sacch. cerevisiae var boulardii; was effective in the treatment of acute diarrhea in children (Cetina and Siemo, 1999; Zeng et al., 2003). And critically ill tube fed patients. Sacch. cerevisiae var.boulardii release polyamines which help in repairing mucous membranes. These polyamines increase the activity of short chain fatty acids (SCFA) and disaccharide enzymes (lactase, maltase, sucrase). Polyamines stimulate the repair of intestinal cells and the growth of colonic mucosa (Buts et al., 1994; Edwards-Ingram et al., 2007). The beneficial properties of Saccharomyces spp. strains are well documented (Rodrigues et al., 1996; Martins et al., 2005). In addition to their nutritive value (e.g. provision of vitamins of the B group), probiotic yeasts are generally resistant to gastrointestinal passage and are resistant to most antibiotics. Yeast preparations have also been successfully applied, in combination with antibiotics, to treat Clostridium difficile -related diarrhea commonly known as antibiotic associated diarrhea. Probiotic Saccharomyces spp. may also help to re-establish a normal gut function, after long term antibiotic therapy (McFarland et al., 1994; Katarzyna and Alina 2010). The recent study aimed to study the isolation and identification of local isolates the yeast Sacch. cerevisiae from different dried and fresh fruits sources in Erbil city; it also studyies the ability of using these isolated yeasts as aprobiotics (Edwards-Ingram et al., 2007; DeVrese and Schrezenmeir, 2008).

\section{Isolation of the yeasts}

\section{MATERIALS AND METHODS}

One hundred and twenty Samples of fresh and dried fruits were collected from different sources that were available in local markets in Erbil city such as lychee, grape, mangosteen, apricot and fig. One gram of fruit sample, blended and mixed with sterilized nine milliliters peptone water then a serial of dilution was made until $10^{-5}$, one $\mathrm{ml}$ of the last dilution was cultured by pour plate method using sabouraud dextrose agar (Oxide) pH 5.5 (Deak and Beuchat, 1987). Morphological appearance and microscopic examination of the colonies were done after staining them with simple stain (methylene blue). 


\section{Identification of isolated yeast:}

As mentioned by (Lodder, 1974; Barnett et al., 1985; Barnett et al., 1990), biochemical tests were done such as; Carbon source fermentation, Nitrogen source utilization, acid production from fermented sugars, Ester production, Urea hydrolysis were tested to isolate yeasts.

\section{Cyclohexamide( Actidione ):}

Two solutions were prepared (Frazier, 1985)

Solution No.1: Prepared by dissolving 10mg actidione in $90 \mathrm{ml}$ distilled water and then sterilized by filtration (Millipore filter $0.22 \mu \mathrm{m}$ ).

Solution No.2: Prepared by dissolving 6.7gm of Yeast Nitrogen Base (YNB) and 1gm glucose in $100 \mathrm{ml}$ distilled water then sterilized by filtration (Millipore filter $0.22 \mu \mathrm{m}$ ), 4.5 $\mathrm{ml}$ of solution No.1 was mixed with $0.5 \mathrm{ml}$ of solution No.2 in sterilized test tubes, the tubes were inoculated with yeast isolates, then incubated at $28{ }^{\circ} \mathrm{C}$, the tubes were monitored weekly. The tubes don't show any growth after three weeks are considered to be very sensitive to the antibiotic.

\section{Antibacterial activity against tested pathogenic bacteria:}

The isolated yeasts were inoculated in Yeast Extract Glucose peptone (YEGP) and incubated at $32^{\circ} \mathrm{C}$ for $24 \mathrm{hr}, 50 \mathrm{ml}$ of the same medium was inoculated by $5 \mathrm{ml}$ of yeast suspension and incubated at $32^{\circ} \mathrm{C}$ for $24 \mathrm{hr}$. The pathogenic bacteria (from Media Center/Erbil) was cultured in nutrient broth at $37^{\circ} \mathrm{C}$ for $3 \mathrm{hr}$, Plates were inoculated by 0.1 $\mathrm{ml}$ of the pathogenic bacteria, left to dry for 15 minutes at $37^{\circ} \mathrm{C}$, 4 wells in each plate (with diameter $5 \mathrm{~mm}$ ) were done using Cork Borer and filled with $0.1 \mathrm{ml}$ of yeast suspension after centrifugation at $3000 \mathrm{rpm}$ for 5 minutes the plates were incubated for $24 \mathrm{hr}$ at $37^{\circ} \mathrm{C}$ then the inhibition zones were measured (Izguet al., 1997).

\section{Study the tolerance of Saccharomyces cerevisiae var. boulardii for some gastrointestinal} conditions (in vitro)

The isolated yeasts were used to examine tolerance to bile salt and gastric acidity which had the best activity against $S$. Typhimurium, the isolated yeasts were (S.b6, S.c1, S.b2, S.c36, S.b13, S.b28, S.b32, S.b22, S.b48, and S.b5).

\section{Bile salt tolerance}

Yeast cultures were activated by two transfers in liquid Yeast Peptone Dextrose (YPD) and inoculated at $32^{\circ} \mathrm{C}$ for $48 \mathrm{hr}$ and centrifuged at $3000 \mathrm{rpm}$ for 10 minutes, then sterile phosphate buffered saline was added to the cells and mixed by vortex mixer, then the tubes contain YPD medium supplemented with different concentrations of bile salt $(0.2,0.4,0.6$, 0.8 , and $1 \%$ ), and inoculated with $\left(10^{6} \mathrm{CFU} / \mathrm{ml}\right)$ of yeast cells. The growth of the yeast cells was estimated after $1,8,16$ and $24 \mathrm{hr}$ of incubation at $32^{\circ} \mathrm{C}$ by measuring absorbance at 660 nm (Katarzyna and Alina, 2010; Bhukya et al., 2010).

\section{Tolerance to acidity}

Yeast cultures were activated in YPD and incubated at $32^{\circ} \mathrm{C}$ for $24 \mathrm{hr}$., then centrifugation at 3000 rpm for 10 minutes. Sterile phosphate buffered saline PBS was added to the cells and mixed by vortex mixer. Tubes containing artificial gastric juice were inoculated with $\left(10^{6} \mathrm{CFU} / \mathrm{ml}\right)$ of yeast cells in which the $\mathrm{pH}$ was adjusted 2.5 (the $\mathrm{pH}$ of stomach). The tubes incubated at $32^{\circ} \mathrm{C}$ and the number of viable cells was determined by plate count method using (colony counter) after 0, 1, 2, 3, 24 hr of incubation (Katarzyna 
and Alina, 2010) and the result expressed as percentage log survival was calculated according to (Williamson and Johnson,1981).

\section{RESULTS AND DISCUSSION}

Fifty isolated yeasts were obtained from different sources such as fresh and dried fruits and all of them were identified by morphological, biochemical and physiological tests,as shown in Table (1). Some taxonomic studies have indicated that Saccharomycesboulardii should be rather considered as Saccharomyces cervisiae. DNA-DNA reassociation studies indicated that this yeast was distinct from Saccharomyces cervisiae (Cardinali and Martini,1994). DNA analysis showed the presence of similarity in the genome of these two yeasts is more than 95 \% (Baleiras et al., 1995; Edwards-Ingram et al., 2004; Dixit and Gandhi, 2006). The yeast Sacch. Cerevisiae should be referred to as Saccharomyces cerevisiae var. boulardii (Czeruckaet al., 2007; Edwards-Ingram et al., 2007; DeVrese and Schrezenmeir, 2008). Nevertheless, Sacch. cerevisiae var boulardii are reported in the scientific reports for their biotherapeutic activities in the prevention of several types of diarrhoea and colitis in humans (Surawiczet al., 1989; McFarland and Bernasconi, 1993).

\section{Antibacterial activity of isolated yeasts against $\mathrm{S}$. Typhimurium}

The inhibitory activity of isolated yeast against $S$. Typhimurium, was shown in Table (2) Saccharomyces cerevisiae var boulardii have an obvious effect against bacterial growth by producing inhibitory substances that prevent the growth of pathogenic bacteria. In using the well diffusion method, isolated yeasts (S.b2, S.b5, S.c36, S.b48, S.b32, S.b13) had larger diameter of inhibition zone which was 15 and $16 \mathrm{~mm}$ and the smallest diameter of inhibition zone was $10 \mathrm{~mm}$ for the isolates (S.c15, S.c19, S.b18, S.c 33). A study proved that Sacch. cerevisiae var boulardii has ability to inhibit the diarrhea causative bacteria $S$. Typhimurium has shown that they strongly adhere to mannose on the surface of Sacch. cerevisiae var boulardii via lectin receptors, once the invading microbe is bound to Sacch. cerevisiae var boulardii, its prevented from attaching to the intestinal cell wall (Gedek,1999). Also it was proved that the yeast could be used for the treatment of diarrhea (Zouch et al., 2000).

Another study showed the antagonistic activity of the yeast against Salmonella, Shigella and E. coli (Zeng et al., 2003). The outer membrane of Sacch cerevisiae var boulardii is rich in mannose, allowing pathogens such as Salmonella and others which contain in their structure type1 pili (mannose-binding fibers) this enables pathogens to bind to this mannose rich membrane and this binding action prevents $E$. coli and other harmful bacteria from adhering to intestinal cells. (Rodrigues et al., 1996).

\section{Tolerance of Saccharomyces cerevesiae var boulardii for some gastrointestinal conditions (in vitro)}

The promising activities of yeasts as well as their ability to survive during the passage through the human gastro-intestinal tract, tolerating exposures to low $\mathrm{pH}$ and to bile salts, have drawn attention to their possible use as probiotics (Lourens-Hattingh and Viljoen, 2001), even if their use for humans is currently restricted (Psomas et al., 2001). Furthermore, few studies have specifically focused on selecting or studying new probiotic yeast strains (Agarwal et al., 2000; Psomas et al., 2001; Martins et al., 2005). 


\section{Bile salt tolerance:}

As shown in (Fig. 1) the isolated (S.b32) had shown the best ability to tolerance bile salts more than the other isolated yeasts and had good growth rate even in $1 \%$ bile salt, next to it (S.b2) had also a good ability to tolerance and the other strains showed different ability for exposure to different concentrations of bile salts. Generally all the isolated yeasts showed different abilities of tolerance to bile salts. Microorganisms that survive in the acidic condition of the stomach also have to survive in intestinal secretion and the bile salts in the duodenum (Erkkila and Petaja, 2000). Bile is yellow green aqueous solution whose major constituent includes bile acids, cholesterol phospholipids and pigment biliverdin (Carey and Duane, 1994; Hofmann,1994). It's synthesized in the pericentral hepatocytes of the liver, stored and concentrated in the gall bladder interdigestivelly, concentration used for the screening of a resistant probiotic strain is $0.3 \% \mathrm{w} / \mathrm{v}$ (Gilliland et al., 1984). Bile resistance is an important criterion in the selection of culture as a dietary adjunct (Gilliland and Walker, 1990; Walker and Gilliland, 1993), because it could allow the growth of the ingested probiotic microorganism in the intestinal tract (Gilliland et al.,1984; Suskovic et al., 1997). and the bile salts in the duodenum (Erkkila and Petaja, 2000). Bile is yellow green aqueous solution whose major constituent include bile acids, cholesterol phospholipids and pigment biliverdin (Carey and Duane, 1994; Hofmann,1994). It's synthesized in the pericentral hepatocytes of the liver, stored and concentrated in the gall bladder interdigestivelly, concentration used for the screening of a resistant probiotic strain is $0.3 \% \mathrm{w} / \mathrm{v}$ (Gilliland et al., 1984). Bile resistance is an important criterion in the selection of culture as a dietary adjunct (Gilliland and Walker, 1990; Walker and Gilliland, 1993), because it could allow the growth of the ingested probiotic microorganism in the intestinal tract (Gilliland et al.,1984; Suskovic et al., 1997).

Table 1: The Results of diagnostic tests used for identification Sacchromyces cerevisiea var.boulardii

\begin{tabular}{|c|c|c|}
\hline \multicolumn{2}{|c|}{ Tests } & \multirow{2}{*}{$\begin{array}{c}\text { Results } \\
+\end{array}$} \\
\hline \multirow{7}{*}{$\begin{array}{l}\text { Utilization of } \\
\text { carbon }\end{array}$} & Glucose & \\
\hline & Fructose & + \\
\hline & Sucrose & + \\
\hline & Galactose & $+/-$ \\
\hline & Raffinose & + \\
\hline & Lactose & - \\
\hline & Starch & + \\
\hline \multirow{4}{*}{$\begin{array}{c}\text { Utilization of } \\
\text { nitrogen }\end{array}$} & Peptone & + \\
\hline & Aspargine & + \\
\hline & Ammonium sulphate & + \\
\hline & Nitrate & - \\
\hline \multicolumn{2}{|c|}{ Acid production } & + \\
\hline \multicolumn{2}{|c|}{ Urea hydrolysis } & - \\
\hline \multicolumn{2}{|c|}{ Ester production } & + \\
\hline \multicolumn{2}{|c|}{ Cyclohexamide Resistance } & - \\
\hline
\end{tabular}


Table 2: Antibacterial activity of isolated yeasts against S.Typhimurium

\begin{tabular}{|c|c|}
\hline Yeast Isolates* & Inhibition zone (mm) \\
\hline S.c 1 & 14 \\
\hline S.b 2 & 15 \\
\hline S.b 3 & 13 \\
\hline S.c 4 & 11 \\
\hline S.b 5 & 15 \\
\hline S.b 6 & 14 \\
\hline $\begin{array}{ll}\text { S.c } 8 \\
\end{array}$ & 12 \\
\hline S.b 9 & 3 \\
\hline S.b 11 & 13 \\
\hline S.c 12 & 12 \\
\hline S.b 13 & 15 \\
\hline S.c 15 & 10 \\
\hline S.b 16 & 12 \\
\hline S.b 17 & 13 \\
\hline S.b 18 & 10 \\
\hline S.c 19 & 10 \\
\hline S.b 20 & 11 \\
\hline S.b 22 & 14 \\
\hline S.c 23 & 11 \\
\hline S.b 24 & 13 \\
\hline S.b 25 & 12 \\
\hline S.c 26 & 13 \\
\hline S.c 27 & 13 \\
\hline S.b 28 & 14 \\
\hline S.c 29 & 12 \\
\hline S.c 31 & 13 \\
\hline S.b 32 & 16 \\
\hline S.c 33 & 10 \\
\hline S.b 34 & 13 \\
\hline S.c 36 & 16 \\
\hline S.c 38 & 11 \\
\hline S.b 40 & 12 \\
\hline S.c 41 & 11 \\
\hline S.b 42 & 13 \\
\hline S.b 43 & 12 \\
\hline S.c 45 & 11 \\
\hline S.c 47 & 11 \\
\hline S.b 48 & 15 \\
\hline S.b 49 & 12 \\
\hline
\end{tabular}

\section{Tolerance to acidity:}

Before reaching the intestinal tract, probiotic yeast must survive transit through the stomach and exposure to gastric acid constituents, which is a primary defense mechanism 
against most ingested microorganisms. (Marteau et al., 1993). It's shown in (Fig. 2) that the isolated yeast strains have the ability to resist acidity, and the strains have different ability to resist low $\mathrm{pH}$. The isolated yeast (S.b32) had highest percentage of survival and the others (S.c36, S.b13, S.b28, S.c1, S.b2, S.b6) also tolerated acidity but compared to strain (S.b32) was lower. The first main barrier that microorganisms after ingestion is exposed to gastric juice, in which the inhibitory effect is strictly related to the $\mathrm{pH}$ and the concentration of hydrochloric acid $\mathrm{HCl}$ (Psomas et al., 2001). The $\mathrm{pH}$ of excreted $\mathrm{HCl}$ in the stomach is 0.9, but the presence of food raises the $\mathrm{pH}$ to 3.0 (Erkkila and Petaja, 2000). Moreover, the presence of food or other food components could buffer the probiotics ingested, conferring some protective effect on the microbial cells in the stomach. (Conway et al.,1987 ; Prasad et al.,1998).

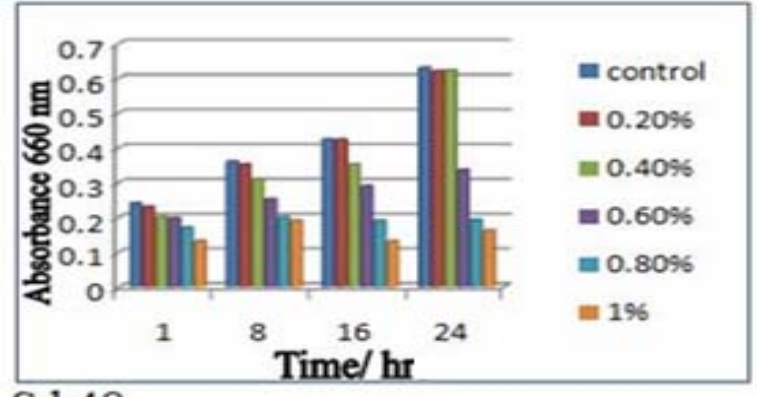

\section{S.b48}

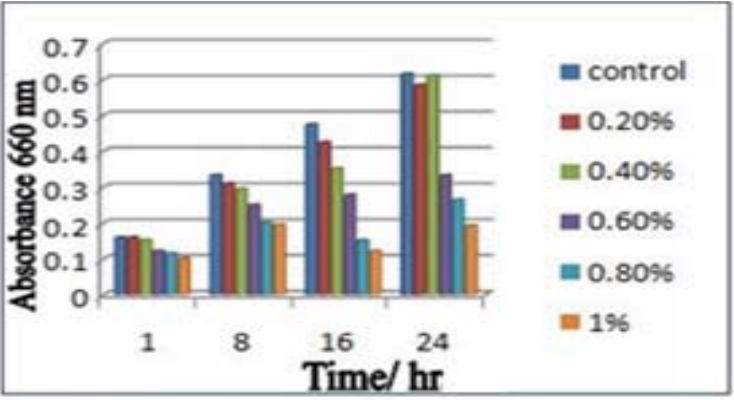

\section{S.b22}

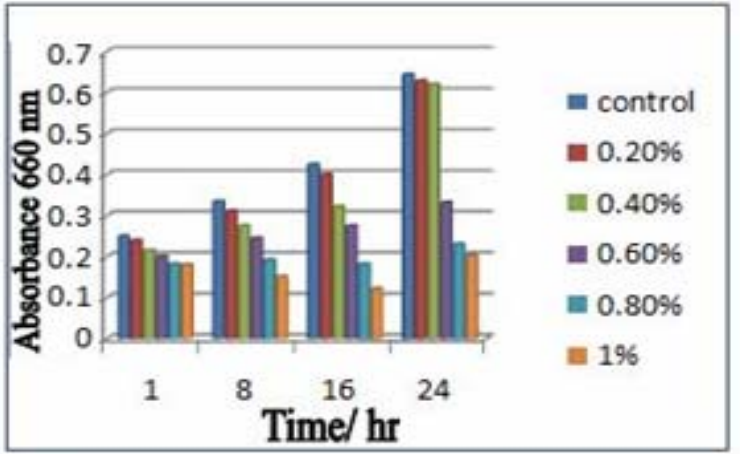

\section{S.b28}



S.b6
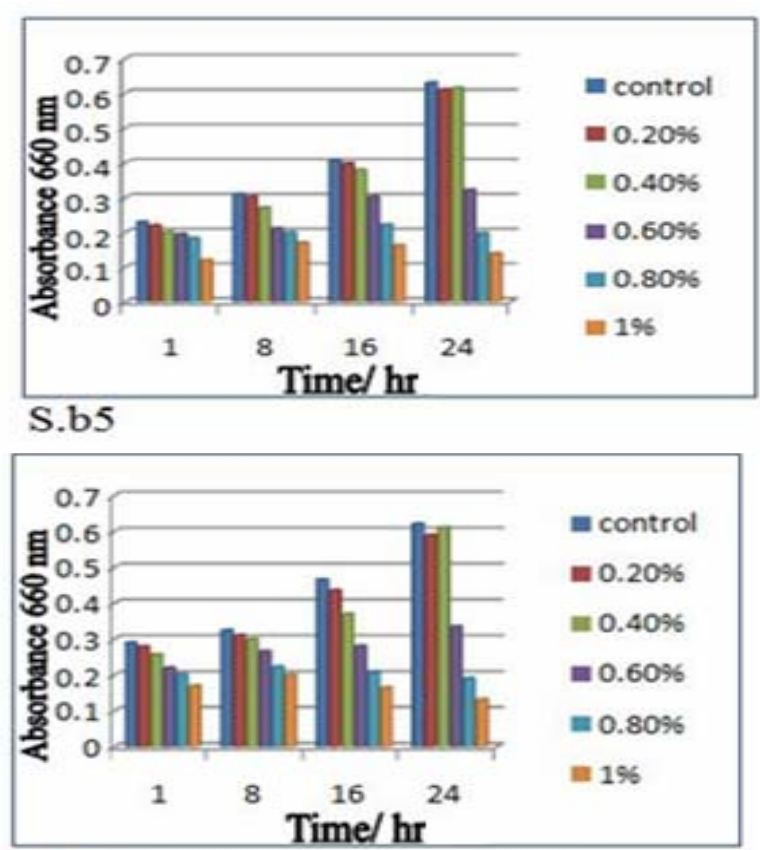

\section{S.b13}

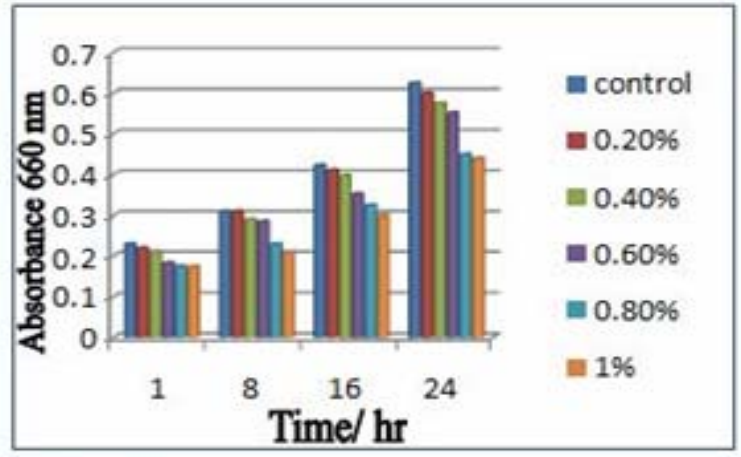

S.b32

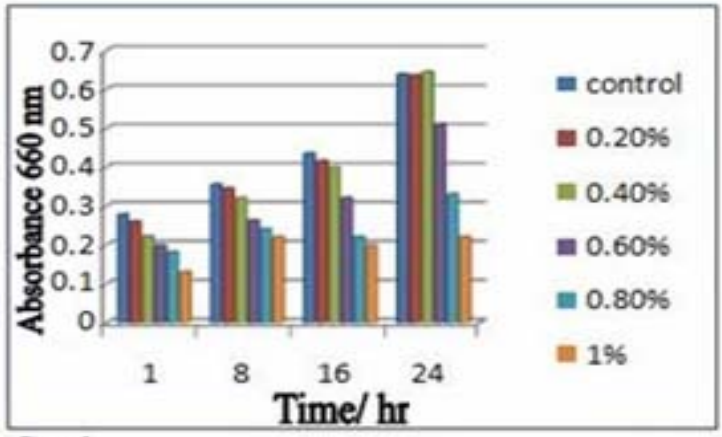

S.c1 


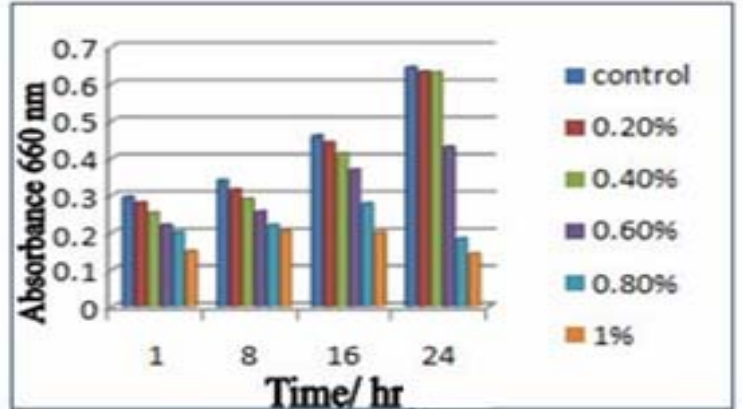

S.c36

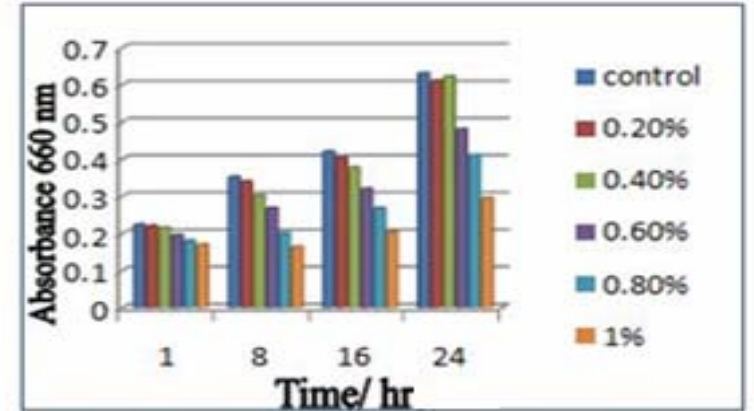

S.b2

Fig. 1: Ability of isolated yeasts to tolerate different concentrations of bile salts
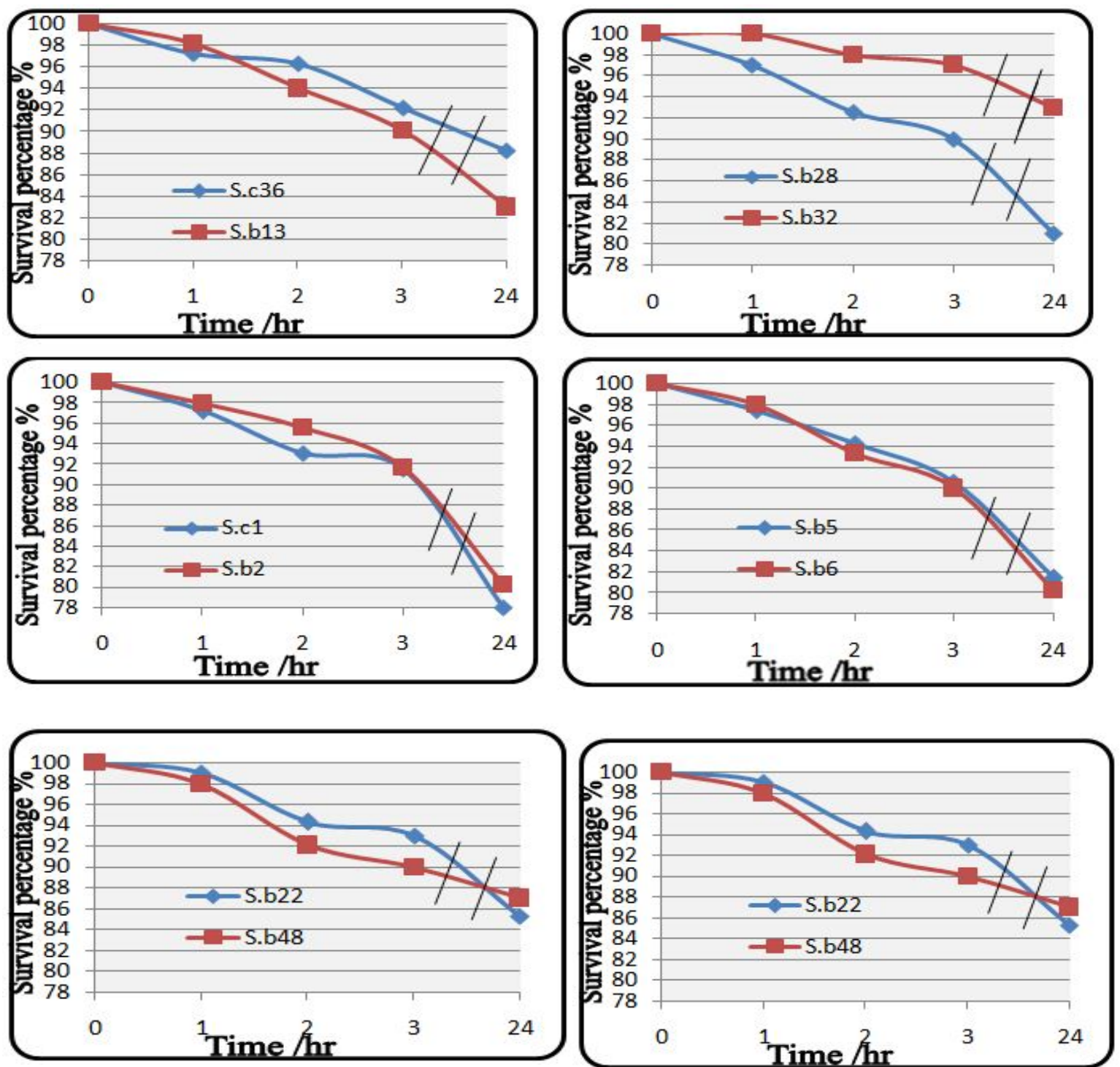

Fig. 2: Percentages of survival of Saccharomyces cerevesiae var boulardii in artificial gastric juice (pH 2.5). 


\section{REFERENCES}

Agarwal, N.; Kamra, D.N.; Chaudhary, L.C.; Sahoo, A.; Pathak, N.N. (2000). Selection of Saccharomyces cerevisiae strains for use as a microbial feed additive. Lett. Appl.Microbiol, 31, 270-273.

Baleiras, M.M.; Vogels, J.T.; Hofstra, H.J.; Huisin’t, J.H.; Van der Vossen, J.M. (1995). Random amplified polymorphic DNA and restriction enzyme analysis of PCR amplified rDNA in taxonomy: two identification techniques for food-borne yeasts. J. Appl. Bacteriol, 79, 525-535.

Barnett, J.A.; Payane, R.W.; Yarrow, D. (1985). "Yeasts Characteristic and Identification". Cambridge University Press. 467p.

Barnett, J.A.; Payne, R.W.; Yarrow, D. (1990). "Yeast Characteristic and Identification". 2nd ed. Cambridge University press. pp.1-1002.

Bhukya, B.; Sudhakara, R.M.; Tangutur, A.D.; Yerradoddi, R.R.; Linga, V.R. (2010). Screen and characterization of stress tolerant Saccharomyces cerevisiae isolated from brewery effluents for animal probiotic applications. The IIOAB J.; ISSN : 0976- 3104.

Buts, J.P.; DeKeyser, N.; DeRaedemaekier, L. (1994). Saccharomyces boulardii enhances rat intestinal enzyme expression by endoluminal release of polyamines. Pediatr. Res., 36, 522-527.

Cardinali, G.; Martini, A. (1994). Electrophoretic karyotypes of authentic strains of the sensustricto group of the genus Saccharomyces. Bacteriol. Int. J. Syst. Bacteriol; 44,791-797.

Carey, M.C.; Duane, W.C. (1994). Enterohepatic circulation. pp. 719-738. In I. M. Arias, N.; Boyer, N.; Fausto, W. B.; Jackoby, D.A.; Schachter, D.A.; Shafritz, "The liver: biology and pathobiology". Raven Press, Ltd., New York.

Cetina, S.G.; Siemo, B.G. (1999). Evaluation therapeutique de Saccharomyces chez des enfantssourffrant de diarrhea aigue. Annales de Pediatrie, 41, 397-400.

Conway, P.L.; Gorbach, S.L.; Goldin, B.R. (1987). Survival of lactic acid bacteria in the human stomach and adhesion to intestinal cells. J. Dairy Sci., 70, 1-12.

Czerucka, D.; Piche, T.; Rampal, P. (2007). Review article: yeast as probiotics Saccharomyces boulardii. Aliment. Pharmacol. Ther., 26, 767-778.

De Vrese, M.; Schrezenmeir, J. (2008). Probiotics, prebioitcs, and synbiotics. Adv. Biochem. Eng. Biotechnol. 111, 1-66.

Deak, T.; Beuchat, R. (1987). Identification of food borne yeasts. J. Food Protect. 50, 243-264.

Dixit, K.; Gandhi, D.N. (2006). "Biotherapeutic properties of probiotic yeast Saccharomyces species in fermented dairy foods". Hill Book Co. New York. pp.134-205

Edwards-Ingram, L.; Gitsham, P.; Burton, N.; Warhurst, G.; Clarke, I.; Hoyle, D.; Oliver, S.G.; Stateva, L. (2007). Geno-typic and physiological characterization of Saccharomyces boulardii, the probiotic strain of Saccharomyces cerevisiae. Appl. and envir. Microbiology, 73, 2458-2467.

Edwards-Ingram, L.C.; Gent, M.E.; Hoyle, D.C.; Hayes, A.; Stateva, L.; Oliver, S.G. (2004). Comparative genomic hybridization provides new insights into the 
molecular taxonomy of the Saccharomyces sensustricto complex. Genome Res.14, 1043-1051.

Erkkila, S.; Petaja, E. (2000). Screening of commercial meat starter cultures at low pH and in the presence of bile salts for potential probiotic use. Meat Sci., 55, 297-300.

Frazier, W.C. (1985). " Food Microbiology". Hill Book Co. New York. pp. 98-122

Gedek, B.R. (1999). Adherence of Escherichia coli sero group O 157 and Salmonella Typhimurium mutant DT 104 to the surface of Saccharomyces boulardii, Mycoses. 42, 261-264.

Gilliland, S.E.; Walker, D.K. (1990). Factors to consider when selecting a culture of Lactobacillus acidophilus as a dietary adjunct to produce a hypocholesterolemic effect in humans. J. Dairy Sci.,73, 905-911.

Gilliland, S.E.; Stanley, T.E.; Bush, L.J. (1984). Importance of bile tolerance of Lactobacillus acidophilus used as a dietary adjunct. J. Dairy Sci., 67, 3045-3051.

Hofmann, A.F. (1994). In Arias, J.L.; Boyer, N.; Fausto, W.B.; Jackoby, D.A.; Schachter, D.A. "The liver: Biology and pathobiology". Raven Press, Ltd., New York. pp. 372-385

Izgu, F.; Altinbay, D.; Yucelis, A. (1997). Identification and Killer activity of yeast contaminating starting culture of Saccharomyces cerevisiae strains used in Turkish baking industry. Food Microbial, 14,125-131.

Katarzyna, R.; Alina, K.S. (2010). Probiotic properties of yeasts isolated from chicken feces and kefirs. J. Microb., 59 (4), 257-263.

Lodder, J. (1974). "The Yeast A Taxonomic Study". North Holland Company, pp.1-103.

Lourens, A.; Viljoen, B.C. (2001). Growth and survival of a probiotic yeast in dairy products. Food Research International, 1 34, 791-796.

Marteau, P.; Pochart, P.; Bouhnik, Y.; Rambaud, J.C. (1993). The fate and effects of transiting, nonpathogenic micro-organisms in the human intestine. In: Simopoulos AP, Corring T, Rérat A. Intestinal flora immunity, nutrition and health. World Rev. Nutr. Diet, 74, 1-21

Martins, F.S.; Nardi, R.M.; Arantes, R.M.E.; Rosa, C.A.; Neves, M.; Nicoli, J.R. (2005). Screening of yeasts as probiotic based on capacities to colonize the gastrointestinal tract and to protect against enteropathogen challenge in mice. J. Gen. Appl. Microbiol, 51, 83-92.

McFarland, L.V.; Bernasconi, P. (1993). Saccharomyces boulardii: A review of an innovative biotherapeutic agent. Microb. Ecol. Hlth. Dis., 6, 157-171.

McFarland, L.V.; Surawicz, C.M.; Greenberg, R.N.; Fekety, R.; Elmer, G.W.; Moyer, K.A. (1994). A randomized placebo controlled trial of Saccharomyces boulardii in combination with standard antibiotics for Clostridium difficile disease. J. Amer. Med. Ass., 271, 1913-8.

Prasad, J.; Gill, H.; Smart, J.; Gopal, P.K. (1998). Selection and characterization of Lactobacillus and Bifidobacterium strains for use as probiotics. Int. Dairy J., 8, 993-1002.

Psomas, E.; Andrighetto, C.; Litopoulou-Tzanetaki, E.; Lombardi, A.; Tzanetakis, N. (2001). Some probiotic properties of yeast isolates from infant feces and Feta cheese. Int. J. F. Microb., 69, 125-133.

Rodrigues, A.C.; Nardi, R.M.; Bambirra, E.A.; Vieira, E.C.; Nicoli, J.R. (1996). Effects of Saccharomyces boulardii against experimental oral infection with Salmonella 
Typhimurium and Shigella flexneri in conventional and guotobiotic mice. J. Appl. Bacteriol., 81, 251-256.

Surawicz, C.M.; Elmer, G.W.; Speelman, P.; McFarland, L.V.; Chinn, J.; Van Belle, G. (1989). Prevention of antibiotic-associated diarrhea by Saccharomyces boulardii: a prospective studies. Gastroenterology, 96, 981-988.

Suskovic, J.; Brkic, B.; Matosic, S.; Maric, V. (1997). Lactobacillus acidophilus M92 as potential probiotic strain. Milchw Iss Enschaft; 52, 430-435.

Walker, D.K.; Gilliland, S.E. (1993). Relationships among bile tolerance, bile salt deconjugation and assimilation of cholesterol by Lactobacillus acidophilus. $J$. Dairy Sci.,76, 956-961.

Williamson, K.J.; Johnson, O.G. (1981). A bacterial assay for assessment of wastewater toxicity. Water Research, 15, 383-390.

Zeng, H.; Carlson, A.Q.; Guo, Y.Yu.Y.; Collier-Hyams, L.S.; Madara, J.L.; Gewirtz, A.T.; Neish, A.S. (2003). Flagellin is the major proinflammatory determinant of enteropathogenic Salmonella. J. Immun, 171, 3668-3674.

Zouch, A.; Loukil, G.; DeLagause, M.; Macry, J.; Fitoussi, F.; Bernasconi, P.; Bingen, E.; Cazard, J.P. (2000). Effects of oral Saccharomyces boulardii on bacterial overgrowth, translocation and intestinal adaptation after small -bowel resection in rats, J. Gastroentrol., 35,160-165 